\author{
Marquette University \\ e-Publications@Marquette
}

9-2019

\title{
Methane Yield and Lag Correlate with Bacterial Community Shift Following Bioplastic Anaerobic Co-Digestion
}

Kaushik Venkiteshwaran

Marquette University

Nicholas Benn

Marquette University

Saba Seyedi

Marquette University

Daniel Zitomer

Marquette University, daniel.zitomer@marquette.edu

Follow this and additional works at: https://epublications.marquette.edu/civengin_fac

Part of the Civil Engineering Commons

\section{Recommended Citation}

Venkiteshwaran, Kaushik; Benn, Nicholas; Seyedi, Saba; and Zitomer, Daniel, "Methane Yield and Lag Correlate with Bacterial Community Shift Following Bioplastic Anaerobic Co-Digestion" (2019). Civil and Environmental Engineering Faculty Research and Publications. 243.

https://epublications.marquette.edu/civengin_fac/243 
Marquette University

e-Publications@Marquette

\section{Civil, Construction and Environmental Engineering Faculty Research and Publications/College of Engineering}

This paper is NOT THE PUBLISHED VERSION; but the author's final, peer-reviewed manuscript. The published version may be accessed by following the link in th citation below.

Bioresource Technology Reports, Vol. 7, (September 2019) : 100198 . DOI. This article is (C) Elsevier and permission has been granted for this version to appear in e-Publications@Marquette. Elsevier does not grant permission for this article to be further copied/distributed or hosted elsewhere without the express permission from Elsevier.

\section{Methane Yield and Lag Correlate with Bacterial Community Shift Following Bioplastic Anaerobic Co-Digestion}

\section{Kaushik Venkiteshwaran}

Department of Civil, Construction and Environmental Engineering, Marquette University, Milwaukee, WI

Nicholas Benn

Department of Civil, Construction and Environmental Engineering, Marquette University, Milwaukee, WI Saba Seyedi

Department of Civil, Construction and Environmental Engineering, Marquette University, Milwaukee, WI Daniel Zitomer 


\section{Abstract}

Past plastic management practices have resulted in pollution. An improved management scenario may involve adding used bioplastic to anaerobic digesters to increase methane for renewable energy. In this work, effects of polyhydroxybutyrate (PHB) bioplastic anaerobic co-digestion with synthetic primary sludge on operation and microbial communities were investigated. Co-digesters treating sludge were co-fed $20 \%$ untreated or pretreated $\left(55^{\circ} \mathrm{C}, \mathrm{pH} 12\right) \mathrm{PHB}$. Pretreament resulted in shorter lag (5 d shorter) before methane production increased after co-digestion. At steady-state, co-digesters converted $86 \%$ and $91 \%$ of untreated and pretreated PHB to methane, respectively. Bacterial communities were different before and after bioplastic co-digestion, whereas no archaeal community change was observed. Relative abundance of 30 significant bacteria correlated with methane production and lag following PHB addition. No previously known PHB degraders were detected following PHB co-digestion. Microbial communities in anaerobic digesters treating synthetic primary sludge are sufficiently capable of co-digesting PHB to produce additional methane.

\section{Keywords}

Archaea, Methanogenesis, Microbial structure function relationship, Plastic, Polyhydroxyalkanoate, Spearman's rank order correlation

\section{Introduction}

Biodegradable polymer alternatives have been developed that could replace plastics derived from fossil fuel. However, most plastics are still currently produced from fossil fuels such as crude oil and are not biodegradable in the timeframe of composting systems (Ali Shah et al., 2008; Geyer et al., 2017). The present lack of appropriate plastic waste management practices has resulted in as much as $79 \%$ of all plastic waste ever generated, estimated at 6300 million metric tons as of 2015 , to amass in the environment or landfills (Geyer et al., 2017). Conventional non-biodegradable plastics, namely single-use plastic packaging, can lead to contamination of land and aquatic environments. In addition, marine plastic pollution has been found to cause ecological damage (Rochman et al., 2016). Plastic can fragment into smaller microplastic particles in the marine environment and act as a transport medium for harmful chemicals to enter the food chain (Mato et al., 2001).

Biodegradable plastic based on polyhydroxybutyrate (PHB) is one promising alternative to fossil-fuelderived plastic (Tokiwa and Calabia, 2004; Tokiwa et al., 2009; Emadian et al., 2017).

PHB bioplastics share similar properties with common thermoplastics such as polypropylene, and can often replace plastics produced from fossil fuel (Kalia et al., 2000; Verlinden et al., 2007). PHB is a form of polyhydroxyalkanoate( $\mathrm{PHA}$ ) polyester produced by various heterotrophic microbes during stressed conditions, such as during carbon feast-famine regimes or nutrient limitation (Verlinden et al., 2007; Roohi et al., 2018). Industrially-relevant bacteria known to produce PHAs include but are not limited to Alcaligenes latus, Cupriavidus necator, and Pseudomonasputida (Kourmentza et al., 2017). The PHB granules stored by microbes internally can be extracted and purified to produce resin that may be used directly or may be copolymerized with other bioplastics to create application-specific blends (Kalia et al., 2000). Bioplastics derived from PHB are essentially completely biodegradable in aerobic and anaerobic engineered or natural environments (Kalia et al., 2000; Getachew and Woldesenbet, 2016). 
PHB bioplastics can lower economic and ecological impacts if the substrate used to produce them is biologically derived or originates from by-products or wastes (Narodoslawsky et al., 2015). For example, methane derived from anaerobic digestion of waste can be used as a substrate to produce PHB by methanotrophic bacteria, specifically Type II Methanotrophs (class Alphaproteobacteria), under aerobic conditions (Pieja et al., 2011a, Pieja et al., 2011b). Methane-derived PHB polymer is currently available from a commercial source (Mango Materials, Inc. Albany, CA, USA).

One plastic management scenario involves collecting and adding used PHB bioplastic to anaerobic digesters to increase methane production for renewable energy or for new bioplastic production. PHB contains no nitrogen and has a theoretical oxygen demand (ThOD) of $1.6 \mathrm{~g}$ ThOD/g PHB and yields $0.66 \mathrm{~L} \mathrm{CH}_{4} / \mathrm{g} \mathrm{PHB}\left(35^{\circ} \mathrm{C}\right)$ calculated from stoichiometric degradation to methane and the Ideal Gas Law, based on Buswell equation (Buswell and Mueller, 1952). PHB is a dense carbon source that could be co-digested with food, animal or municipal waste containing excess nitrogen (Wang et al., 2015; Benn and Zitomer, 2018). The biochemical pathway of anaerobic PHB biodegradation yields acetate, butyrate, and $\mathrm{H}_{2}$, which are readily degradable methanogenic substrates capable of supporting both acetoclastic and hydrogenotrophic methanogens (Janssen and Schink, 1993). Some existing municipal water reclamation facilities have excess capacity and could digest bioplastic in addition to municipal wastewater sludge to generate more methane. Additionally, PHB can be stored on-site to provide a consistent digester feedstock. The cycle of methane to PHB to methane or renewable energy could yield a more sustainable cradle-to-cradle plastic management scenario (Pieja et al., 2011b; Criddle et al., 2014; Getachew and Woldesenbet, 2016).

(1) $\mathrm{C}_{4} \mathrm{H}_{6} \mathrm{O}_{2}(\mathrm{PHB})+1 \frac{1}{2} \mathrm{H}_{2} \mathrm{O} \rightarrow 2 \frac{1}{4} \mathrm{CH}_{4}+1 \frac{3}{4} \mathrm{CO}_{2}$

Continuous anaerobic digestion or co-digestion of PHB bioplastics to increase methane production has not been thoroughly investigated. In short-term, batch studies, the biochemical methane potential (BMP) values of five commercially available bioplastics including two PHB bioplastics produced from fermentation of D-glucose were determined and approximately $67 \%$ of the ThOD in raw PHB was converted to methane in $40 \mathrm{~d}$ under mesophilic conditions (Benn and Zitomer, 2018). Other studies have reported bioplastic digestion to methane with conversion efficiencies ranging from $39 \%$ in $5 \mathrm{~d}$ to $100 \%$ in 98 d under mesophilic conditions (Budwill, 1996; Yagi et al., 2014).

Typically, initial hydrolysis of macromolecules such as PHB bioplastic is often the rate-limiting step for methane production. Pretreatment of PHB polymers using chemical and thermal processing could facilitate hydrolysis resulting in more rapid bioplastic transformation to methane. Pretreatment under alkaline conditions at elevated temperatures has been shown to increase hydrolysis rates resulting in release of water-soluble products such as 3-hydroxybutyrate and crotonate that can support growth of anaerobic microbes and support methanogenesis (Dörner and Schink, 1990; Janssen and Harfoot, 1990; Yu et al., 2005). Pretreatment at $55^{\circ} \mathrm{C}$ and $\mathrm{pH} 12$ for 24 or $48 \mathrm{~h}$ increased methane production from PHB from 67\% to $91 \%$ (Benn and Zitomer, 2018).

The abundance of PHB degrading bacteria in anaerobic digester biomass also ostensibly affects the rate and extent of PHB conversion to methane. PHB bioplastics can be hydrolyzed by water soluble endogenous carboxylesterase, like PHA depolymerase or lipase, which disrupt the ester

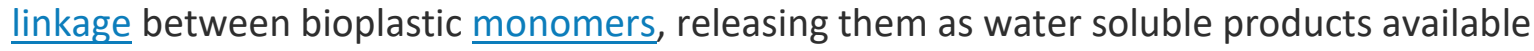


for microbial metabolism (Yoshie et al., 2002). A review by Emadian et al. (2017) provided a list of isolated bacterial and fungal PHB degrading microorganisms in natural environments. The PHB degrading bacterial isolates were classified in the genera Streptomyces, Burkholderia, Bacillus, Cupriavidus, Mycobacterium, Nocardiopsis, Pseudomonas, Enterobacter and Gracilibacillus (Emadian et al., 2017). Most known PHB degrading bacteria have been isolated from compost or natural environments such as soil or river sedimentscontaminated by PHB, whereas there is no published work which has reported on the microbial community composition during anaerobic co-digestion of PHB bioplastics to our knowledge. Presence or enrichment of PHB degrading bacteria during anaerobic PHB co-digestion, and correlation between their abundance and digester performance could lead to strategies such as appropriate starting biomass selection or bioaugmentation to improve co-digester performance. In this study, bench scale, continuously fed, anaerobic co-digesters were used to convert two different untreated and pretreated PHB bioplastics as well as synthetic municipal primary sludge to biogas containing methane. Digester function and microbial community composition before and after initiation of PHB co-digestion were determined. Key taxa exhibiting significant relative abundance shifts after PHB was fed were correlated with observed digester methane yield and lag time.

\section{Materials and methods}

\subsection{Bioplastic processing and pretreatment}

Two different PHB bioplastics, ENMAT ${ }^{\mathrm{TM}}$ Y3000, TianAn BiologicMaterials Co., China (PHB1), which is a fine powder and Mirel ${ }^{\mathrm{TM}}$, Yield10 Bioscience, Inc., Woburn, MA, USA (PHB2), which is in pelletform, were employed. The two different commercially available PHBs were used to discern if the source and form of PHB affects anaerobic bio-degradability. Bioplastic pellets were processed before anaerobic digestion using methods reported elsewhere (Witt et al., 2001; Yagi et al., 2013). Briefly, bioplastic was immersed in liquid nitrogen for 5 min to make it brittle and easier to grind in a laboratory blender (Waring 700G Commercial Blender). Ground bioplastic was sieved and the fraction with nominal particle size $<0.15 \mathrm{~mm}$ was anaerobically digested or pretreated before digestion.

Aliquots of processed bioplastic were pretreated in an effort to increase methane production. PHB1 was pretreated at $55^{\circ} \mathrm{C}$ and $\mathrm{pH} 12$ for $24 \mathrm{~h}$, whereas PHB2 was pretreated at $55^{\circ} \mathrm{C}, \mathrm{pH} 12$ for $48 \mathrm{~h}$. These conditions were shown in previous work to result in maximum biochemicalmethane potential (BMP) increases compared to untreated controls (Benn and Zitomer, 2018).

\subsection{Anaerobic digesters}

Eight, $2.5 \mathrm{~L}$ anaerobic digesters with $2 \mathrm{~L}$ working volume were operated for $175 \mathrm{~d}$. Digesters were continuously stirred-tank reactors (CSTRs), mixed at $350 \mathrm{rpm}$ using a magnetic stir bar and operated with a $15-\mathrm{d}$ hydraulic retention time (HRT) at $35^{\circ} \mathrm{C}$. Digesters were seeded with mesophilic anaerobic digester biomass ( $35 \mathrm{~g}$ VS/L) from a municipal water resource recovery facility (South Shore Water Reclamation Facility, Oak Creek, WI). During the pre-co-digestion period from days 1 to 115, all digesters were fed synthetic municipal primary sludge (SMPS) at an organic loading rate (OLR) of $3.6 \mathrm{~g}$ $\mathrm{COD} / \mathrm{L}-\mathrm{d}$ without bioplastic as a co-digestate. After the pre-co-digestion period, untreated or pretreated PHB bioplastics were co-fed with SMPS during the post-co-digestion period from days 116 to 175 . The PHB bioplastic OLR was 0.75 g COD/L-d, which was $20 \%$ of the SMPS OLR. 
SMPS was composed of ground dog food $(1.21 \pm 0.12 \mathrm{~g}$ COD/g TS) sieved to $<0.8 \mathrm{~mm}$ particle size having approximately $21 \%$ protein and $13 \%$ fat (Nutro Natural Choice, Franklin, TN, USA). The SMPS feed also contained basal nutrients and alkalinity in the following concentrations [mg/L]: $\mathrm{NH}_{4} \mathrm{Cl}[400]$; $\mathrm{MgSO}_{4} * 7 \mathrm{H}_{2} \mathrm{O}$ [400]; $\mathrm{KCl}\left[400\right.$ ]; $\mathrm{Na}_{2} \mathrm{~S}^{*} 9 \mathrm{H}_{2} \mathrm{O}$ [300]; $\mathrm{CaCl}_{2} * 2 \mathrm{H}_{2} \mathrm{O}$ [50]; $\left(\mathrm{NH}_{4}\right)_{2} \mathrm{HPO}_{4}$ [80]; $\mathrm{FeCl}_{3} * 4 \mathrm{H}_{2} \mathrm{O}$ [10]; $\mathrm{CoCl}_{2} * 6 \mathrm{H}_{2} \mathrm{O}$ [1.0]; $\mathrm{ZnCl}_{2}$ [1.0]; $\mathrm{KI}[10] ;\left(\mathrm{NaPO}_{3}\right)_{6}$ [10]; the trace metal salts: $\mathrm{MnCl}_{2} * 4 \mathrm{H}_{2} \mathrm{O}, \mathrm{NH}_{4} \mathrm{VO}_{3}$, $\mathrm{CuCl}_{2} * 2 \mathrm{H}_{2} \mathrm{O}, \mathrm{AlCl}_{3} * 6 \mathrm{H}_{2} \mathrm{O}, \mathrm{Na}_{2} \mathrm{MoO}_{4} * 2 \mathrm{H}_{2} \mathrm{O}, \mathrm{H}_{3} \mathrm{BO}_{3}, \mathrm{NaWO}_{4} * 2 \mathrm{H}_{2} \mathrm{O}$, and $\mathrm{Na}_{2} \mathrm{SeO}_{3}$ [each at 0.5]; cysteine [10]; yeast extract [100] and $\mathrm{NaHCO}_{3}$ [6000]. The SMPS composition was used in previous studies to simulate primary municipal sludge (Carey et al., 2016; Benn and Zitomer, 2018).

The eight digesters were divided into four sets of duplicates digesters. The first and second digester sets were fed SMPS with untreated and pretreated PHB1 bioplastic, respectively. The third and fourth digester sets were fed SMPS with untreated and pretreated PHB2 bioplastic, respectively. Lag time was defined as the period from day 115 (when PHB co-digestion was initiated) until the first day the methane production rate increased to the average methane production rate observed during the subsequent, post-co-digestion quasi steady-stateperiod. Quasi steady-state was defined as the period after digester operation had been previously maintained under consistent conditions for at least three solids retention times (SRTs) (i.e., $45 \mathrm{~d}$ ).

\subsection{DNA extraction and illumina sequencing analyses}

DNA was extracted and sequenced to monitor microbial communitycomposition as described elsewhere (Carey et al., 2016; Venkiteshwaran et al., 2017). Digester effluent samples were collected for DNA extractionduring the pre-co-digestion quasi steady-state period (days 91, 99 and 105), the transition period (days 121, 129 and 135) and the post-co-digestion quasi steady-state period (days 161, 168 and 175). DNA was extracted using the PowerSoil ${ }^{\mathrm{TM}}$ DNA Isolation Sample Kit (MoBio Laboratories, Inc., Carlsbad, CA, USA) according to the manufacturer protocol. Sequencing was performed using the Illumina MiSeq v3 300 base pair sequencing platform (Illumina, San Diego, CA). Universal primers 515F and 806R targeting the V4 variable region of 16S rRNA gene were used for PCR amplification. Raw unjoined sequence data were quality filtered (mean sequence quality score $>25$ ). Barcodes and primers were removed from the sequences. Sequences with ambiguous base reads, fewer than 150 base pairs, and with homopolymer sequences exceeding 6 base pairs or longer were also removed. The de-noised sequences were then clustered into operational taxonomic units (OTUs) having $97 \%$ similarity. Each OTU was compiled into taxonomic "counts" and classified using BLASTn against a curated database derived from GreenGenes, RDPII and NCBI.

\subsection{Major, minor and significant OTUs}

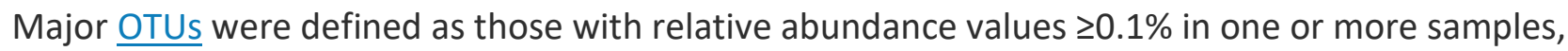
whereas minor OTUs were those with relative abundance $<0.1 \%$ in all samples. Spearman's rank order correlation was performed using major OTUs to select significant OTUs with relative abundance values in all digesters that correlated with average methane production rate, as described elsewhere (Venkiteshwaran et al., 2017). Spearman's rank order correlation was used as a measure of monotonicstatistical dependence due to its robustness since it does not require underlying assumptions regarding the distribution frequency of variables (e.g., normal or uniformly distributed etc.) or the existence of a linear relationship between variables (Zuur et al., 2007). Only the quasi steady state pre- and post-co-digestion periods were considered for Spearman's order rank correlation. 
Major OTUs with relative abundance values that most positively related (i.e., Spearman's rank scores $>0.75$ ) and most negatively related (i.e., Spearman's rank scores less than -0.75 ) to methane production rates were categorized as significant OTUs.

\subsection{Microbial community analyses}

Richness (S), Shannon diversity $(H)$ and evenness $(E)$ indices were calculated using abundance data for all OTUs. Richness was calculated as the number of OTUs identified at the genus level. ShannonWeaver diversity indices were determined as described by Briones et al. (2007). Evenness was calculated as described by Falk et al. (2009). Sequence readswere rarefied to even depth in R Studio with Phyloseq package using "rarefy_even_depth" (rngseed 3), 430 OTUs were removed due to zero reads present after random subsampling (Mcmurdie and Holmes, 2013). Analysis of similarities (ANOSIM) using Bray-Curtis dissimilarity was performed to compare the variation in taxa abundance values using the vegan package in $R$ (Oksanen et al., 2016). ANOSIM analysis gives an ANOSIM statistic value $(R)$ and a $p$ value (significance of $R$ ). $\underline{R}$ valuesclose to 1 suggest high dissimilarity between groups, whereas values close to zero suggest no difference between groups. Spearman's rank order correlation was performed using Excel 2010 (Version 14.3.2 e Microsoft, USA) with the added statistical software package XLStat Pro 2014 (Addinsoft, USA). Non-metric dimensional scaling (NMDS) plots were produced using R Studio with Phyloseq package using "ordinate()" with Bray-Curtis distances and constructed with "plot_ordination()". Sample group ellipses at 95\% confidence level were overlaid using "stat_ellipse()" from ggplot package (Fox and Weisberg, 2011; Mcmurdie and Holmes, 2013). Dual hierarchical clustering of pre and post-co-digestion samples was done in R Studio using "cor()" and "hclust" functions, and a heatmap was made in Excel 2010. Blast searching of representative sequences was conducted using default settings and excluding uncultured sequences on the browserbased blastn tool (https://blast.ncbi.nlm.nih.gov/) (Altschul et al., 1990).

\subsection{Anaerobic digester performance analyses}

Biogas was collected daily in gas sampling bags (Kynar PVDF 20.3 L, Cole Parmer, Vernon Hills, IL, USA) and the volume was measured with a wet test gas meter (Precision Scientific, Chicago, IL, USA). Biogas methane concentration was quantified by gas chromatography (GC System 7890A, Agilent

Technologies, Irving, TX, USA) using a thermal conductivity detector. Volatile fatty acid (VFA) concentrations were measured by gas chromatography (GC System 7890A, Agilent Technologies, Irving, TX, USA) using a flame ionization detector. Volatile Solids (VS) and COD were determined by standard methods (APHA et al., 1999) and the $\mathrm{pH}$ was measured using a $\mathrm{pH}$ meter and probe (Orion 4 Star, Thermo, Waltham, MA, USA). Average, standard deviation, variance and ANOVA calculations were performed using Excel 2010 (Version 14.3.2 e Microsoft, USA).

\section{Results and discussion}

\subsection{Anaerobic co-digester function}

During the pre-co-digestion quasi steady state period (Days 90 to 115) all digesters were operated similarly, and digester methane production rates were similar ( $p$ value $>0.05, n=8$ ), averaging $1.9 \pm 0.02 \mathrm{~L}-\mathrm{CH}_{4} / \mathrm{L}-\mathrm{d}$ ( $\underline{\text { Fig. } 1}$, Co-digestion functional meta data). All digester $\mathrm{pH}$ values remained stable and the effluent total VFA concentration averaged $48 \pm 4 \mathrm{mg} / \mathrm{L}$ as acetic acid $(n=8)$ (co-digestion functional meta data). The addition of PHB bioplastic as a co-digestate on Day 116 initially resulted in 
highly variable methane production in co-digesters (ig. 1). Subsequently, the methane production rate in all co-digesters increased by Day 160 as a result of PHB co-digestion.
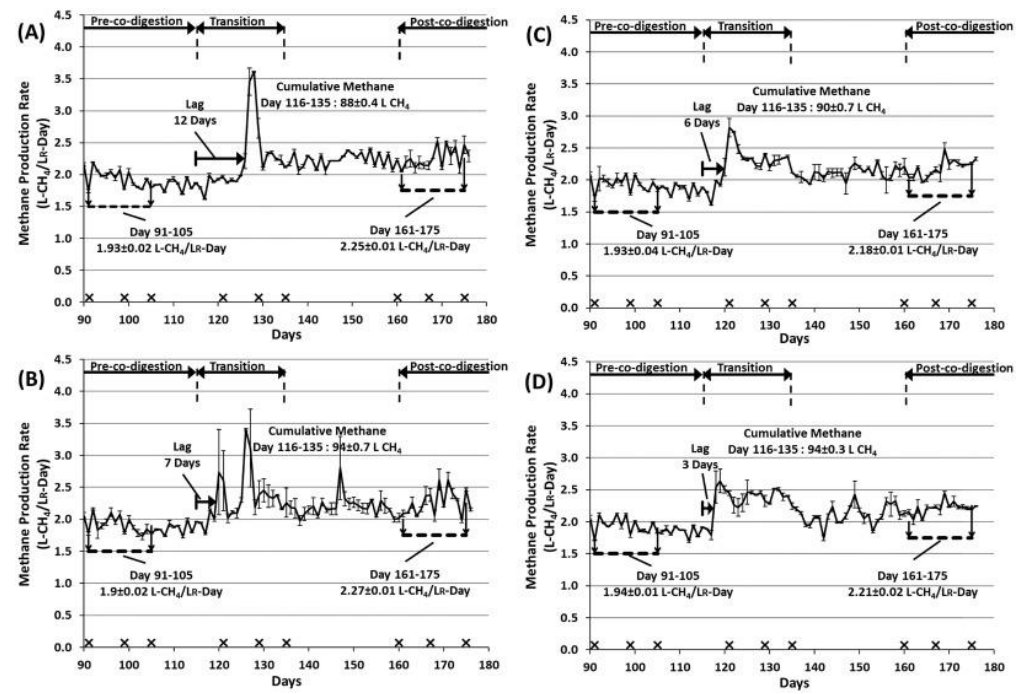

Fig. 1. Digesters average methane production at $35^{\circ} \mathrm{C}$ co-digesting (A) untreated PHB1, (B) pretreated PHB1, (C) untreated PHB2, and (D) pretreated PHB2 with SMPS. Quasi steady-state periods before and after PHB codigestion began are depicted at the top of each figure along with the transition period immediately after the start of PHB co-digestion. Sampling times for microbial community analysis are represented by " $\mathrm{X}$ ". Error bars are standard deviation $(n=2)$.

Pretreating the PHB bioplastics at high $\mathrm{pH}$ and temperature reduced the lag time before PHB codigestion commenced and increased methane production immediately after PHB began to be codigested. The lag times were 3 to $5 \mathrm{~d}$ shorter for digesters fed pretreated versus untreated PHBs (Fig. 1). The shorter lag times also resulted in higher cumulative methane production during the post-codigestion transition period (days 116 to 135). Also, the cumulative methane production from pretreated PHBs was 4.4 to $6.8 \%$ higher than that from untreated PHBs during the transition period (Fig. 1).

Methane production during the post- co-digestion steady state period was $16 \%$ higher than that observed before bioplastics were co-fed. The total OLR when PHB was co-fed was $20 \%$ higher than when digesters were fed SMPS alone. Similar to the pre-co-digestion quasi steady state period, digester $\mathrm{pH}$ remained stable and the effluent VFA concentrations remained lower than $50 \mathrm{mg} / \mathrm{L}$. In previous research, batch biochemicalmethane potential (BMP) testing over $40 \mathrm{~d}$ resulted in 50 to $80 \%$ and 82 to $100 \%$ PHB conversion to methane for raw and thermo-chemically pretreated PHB, respectively (Benn and Zitomer, 2018). Optimal thermochemical pretreatment of PHBs resulted in approximately $20 \%$ increases in BMP values; therefore, those pretreatments were used in this study. In 21-d batch experiments, Budwill et al. (1992) observed $87 \%$ conversion of PHB to methane and up to 96\% conversion for a related PHA co-polymer. Similarly, Yagi et al. (2014) observed 92 to 93\% conversion of PHB to methane during 26-d, batch anaerobic digestion. Therefore, the continuously-fed PHB co-digesters operating at 15-d HRT resulted in methane conversion efficiencies similar to those observed in previous batch experiments. 
There was no long-term difference between methane production for untreated and pretreated PHB bioplastics during co-digestion. Methane production during the post- co-digestion quasi steady state period (Days 160 to 175) for all digesters was similar ( $p$ value $>0.05, n=8$ ) and averaged $2.2 \pm 0.02 \mathrm{~L}$ $\mathrm{CH}_{4} / \mathrm{L}$-d. PHB conversion efficiency to methane during post-co-digestion quasi steady state was $93 \pm 42$ and $79 \pm 21 \%$ for untreated PHB1 and PHB2, respectively, and $98 \pm 4$ and $84 \pm 1 \%$ for pretreated PHB1 and $\mathrm{PHB} 2$, respectively. Duplicate digesters receiving pretreated PHB had notably less variation than those with untreated PHB during the quasi steady state. A $5 \pm 0.1 \%$ increase in PHB conversion efficiency was observed when PHBs were pretreated but this difference was not statistically significant. However, the most benefit from PHB pretreatment during co-digestion was related to a reduced lag time to attain quasi-steady state methane production, reducing this acclimationperiod by nearly $50 \%$.

\subsection{Microbial community analyses}

Illumina sequencing yielded 15.5 million raw sequences, with $215,466 \pm 55,825(n=72)$ raw reads per sample. After 123,995 sequence reads (i.e., lowest sequence reads per sample), the number of OTUs was saturated as revealed by the asymptotic nature of the rarefaction curves and resulted in significant coverage. Therefore, a total of 8.7 million sequence reads from all 72 digesters samples were analyzed with 123,995 rarified sequence reads per sample. Based on $97 \%$ similarity, a total of 14,926 OTUs were observed with an average of $3503 \pm 192$ OTUs per sample.

The microbial community composition data from individual digesters during a given time period were more similar to each other than they were to microbial communities in other digesters as indicated by ANOSIM results $(R=0.95, p=0.001)$. Alpha diversity indices such as richness, Shannon-Weaver diversity and evenness did not correlate with observed pre- or post-co-digestion digester methane production rates.

Digester microbial communities were significantly different before and after bioplastic co-digestion (Fig. 2). Initially, all digester microbial communities were similar to each other during pre-co-digestion when SMPS without PHB was fed (ANOSIM R =0.55, $p=0.001$ ) (Fig. 2). However, after PHB feeding commenced, the microbial communities clustered separately from those of the pre-co-digestion period (ANOSIM R = 0.82, $p=0.001$ ) (Fig. 2). 
Pre-co-digestion Period
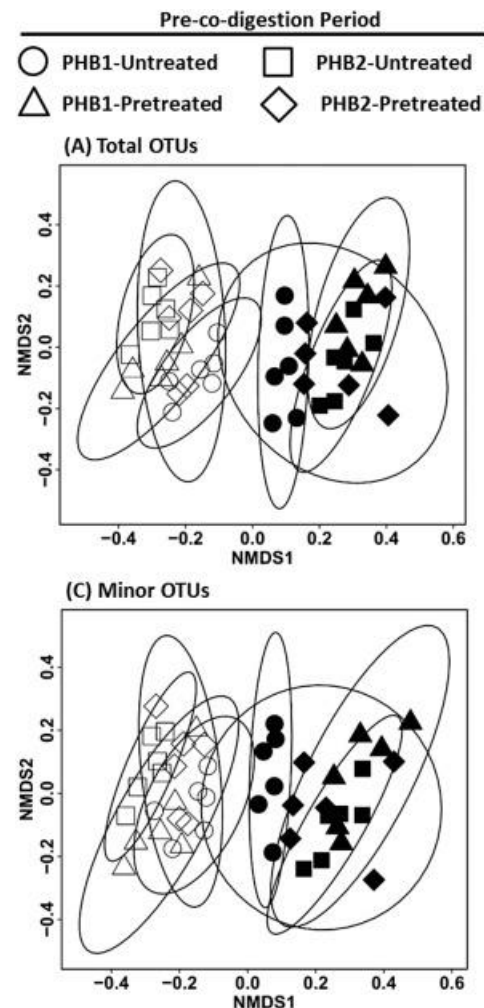

Post-co-digestion Period

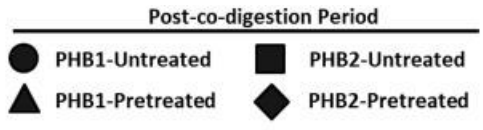

(B) Major OTUs
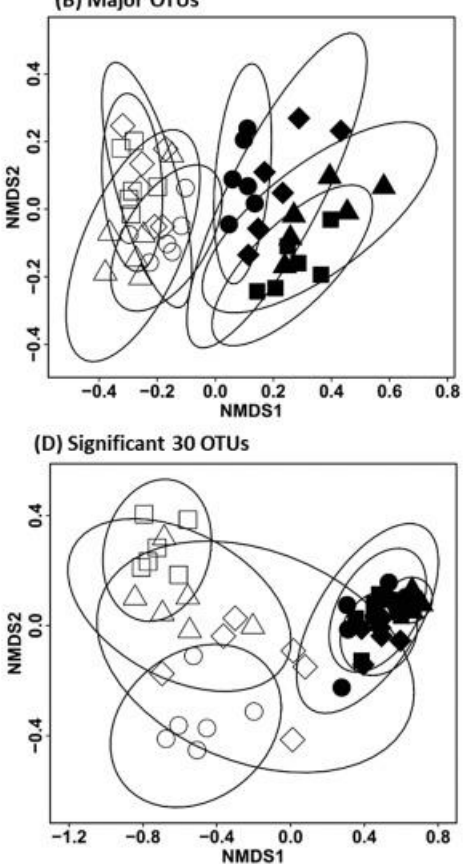

Fig. 2. Communities comparison NMDS plots during pre- and post-co-digestion periods for digesters based on (A) total microbial OTUs, (B) major OTUs (i.e., $\geq 0.1 \%$ relative abundance in at least one sample), (C) minor OTUs (i.e., $<0.1 \%$ relative abundance) and (D) 30 significant OTUs having relative abundance values related to methane production rate using Spearman's rank correlation.

Factors such as the PHB type and whether or not the PHB was pretreated were not observed to affect the microbial communitychanges. Although the microbial communities shifted after co-digestion started, all digester microbial communities converged during the post-co-digestion steady state period (ANOSIM R = 0.61, p = 0.001) (Fig. 1).

A total of 366 major OTUs having $\geq 0.1 \%$ relative abundance in at least one sample were identified that accounted for $88.5 \pm 0.7 \%$ of the total microbial abundance. The remaining 14,560 minor OTUs with lower $(<0.1 \%)$ relative abundance accounted for $11.5 \pm 0.003 \%$ of the total abundance. Both major and minor OTU relative abundance values changed after PHB co-digestion began (Fig. 2B and C). The observed microbial community differences between pre- and post-co-digestion periods using major (ANOSIM R = 0.83, $p=0.001$ ) and minor (ANOSIM R =0.81, $p=0.002$ ) OTU data were similar to that observed using total OTUs (Fig. 2A, B and C). Major shifts in microbial communities during co-digestion of municipal sewage solids and fat, oil and grease (FOG) also have been reported due to change in the feed composition (Kurade et al., 2019).

\subsubsection{Major Bacterial OTUs}

Relative abundance values of major bacterial OTUs during pre- and post-co-digestion period significantly changed after PHB bioplastic was fed to the co-digesters (ANOSIM R =0.87, $p=0.001$ ). The 342 major bacterial OTUs represented a total of 14 phyla. Relative abundance of two bacterial phyla significantly changed due to PHB co-digestion: the relative abundance of Cloacimonetes increased from 
$4.0 \pm 1.8 \%$ to $8.8 \pm 2.8 \%$ ( $p$ value $<0.05, n=48$ ) and Chloroflexi decreased from $2.8 \pm 1.1 \%$ to $0.6 \pm 0.2 \%$ ( $p$ value $<0.05, n=48$ ), respectively, from pre- to post-co-digestion

periods. Bacteroidetes and Firmicutes were consistently the two most dominant phyla in all codigesters during both pre- and post-co-digestion periods, with major bacterial relative abundance values during the pre-co-digestion period of $35 \pm 3.9 \%$ and $22 \pm 2.0 \%$, respectively; these values did not change significantly ( $p$ value $>0.05, n=48$ ) during post-co-digestion. Similarly, the relative abundance of phyla Proteobacteria, Deferribacteres, Synergistetes, Thermotogae and Actinobacteria did not change significantly ( $p$ value $>0.05, n=48$ ) from their pre-co-digestion values of $7.3 \pm 1.1 \%, 5.8 \pm 3.9 \%$, $5.2 \pm 1.1 \%, 3.0 \pm 1.2 \%$ and $1.6 \pm 0.6 \%$, respectively.

\subsubsection{Major Archaeal OTUs}

There were 14 major archaeal OTUs observed in all samples. During the pre-co-digestion period, the combined relative abundance of the major archaeal OTUs ranged from 1.1 to $5.8 \%$. The dominant archaeal OTU was most similar to Methanosaeta and accounted for $3.0 \pm 1.2 \%$ of the total microbial abundance and $89.6 \pm 3.4 \%$ of the total archaeal abundance during the pre-co-digestion period.

Despite the increase in OLR and methane production, PHB co-digestion had no significant influence on the archaeal community composition or archaeal relative abundance. No significant major archaeal OTU community change was observed after the digesters attained post-co-digestion quasi steady state period. The pre- and post-co-digestion archaeal community clustered together and were relatively similar (ANOSIM R =0.07, $p=0.03$ ). Methanosaeta remained the dominant archaeal OTU, accounting for $4.3 \pm 2.2 \%$ of the total microbial community and $90.6 \pm 6.7 \%$ of the total archaeal abundance during the post-co-digestion period.

Methanosaeta have a lower growth rate and higher affinity for acetate than the only other known aceticlastic methanogen genera (Methanosarcina). They typically outcompete Methanosarcina in digesters with low acetate concentration (<500 mg/L) (Conklin et al., 2006; Hori et al., 2006). Since the co-digesters in this study had total VFA concentration of $<50 \mathrm{mg} / \mathrm{L}$ during pre- and post-co-digestion periods, the presence of Methanosaeta as the dominant aceticlastic methanogen was reasonable.

\subsubsection{Spearman correlation to select significant OTUs}

Major OTUs of 48 digester samples (24 from pre- and post-co-digestion period, respectively) were correlated with the observed methane production rate on the days the samples were taken.

Spearman's rank order correlation analysis yielded 30 significant OTUs with relative abundance values correlating to co-digester methane production (Fig. 2D). All significant OTUs were bacteria, whereas no archaea were identified. Of the 30 significant OTUs, 16 were positively correlated and 14 were negatively correlated with methane production (Table 1). Though the archaeal community is important for a stable functioning digester, the results indicates that the bacterial community may have played a more crucial role, as bacterial hydrolysis is ostensibly the rate limiting step during PHB co-digestion. 
Table 1. Blast search result of the Spearman correlated 30 significant OTUs. Of the 30 selected OTUs, 16 OTUs were positively and 14 OTUs were negatively correlated with methane production. Taxonomic classification in bold font represents the valid level based on percent homology with the homology percentage ranges in parentheses. Relative abundance ranges and averages are for 24 samples.

\begin{tabular}{|c|c|c|c|c|c|c|c|c|c|}
\hline & $\begin{array}{l}\text { OT } \\
\text { U \# }\end{array}$ & $\begin{array}{l}\text { Phylum } \\
\text { (>77\%) }\end{array}$ & Class (80-85\%) & Order (85-90\%) & Family (90-95\%) & $\begin{array}{l}\text { Genus (>95\% } \\
\text { homology) }\end{array}$ & $\begin{array}{l}\text { Percent } \\
\text { homolo } \\
\text { gy }\end{array}$ & $\begin{array}{l}\text { Pre-co- } \\
\text { digestio } \\
\text { n } \\
\text { relative } \\
\text { abundan } \\
\text { ce range } \\
\&(A v g), \\
\%\end{array}$ & 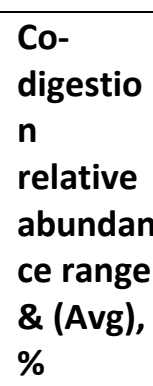 \\
\hline \multirow{8}{*}{$\begin{array}{l}\text { Positivel } \\
\text { y } \\
\text { correlat } \\
\text { ed OTUs }\end{array}$} & $\begin{array}{l}\text { OT } \\
\text { U } 1\end{array}$ & $\begin{array}{l}\text { Deferribacte } \\
\text { res }\end{array}$ & Deferribacteres & Deferribacterales & Deferribacteraceae & Deferribacter & 91.4 & $\begin{array}{l}0.01 \text { to } \\
0.08 \\
(0.05)\end{array}$ & $\begin{array}{l}0.06 \text { to } \\
0.15 \\
(0.10)\end{array}$ \\
\hline & $\begin{array}{l}\text { OT } \\
\text { U } 2\end{array}$ & $\begin{array}{l}\text { Deferribacte } \\
\text { res }\end{array}$ & Deferribacteres & Deferribacterales & Deferribacteraceae & Deferribacter & 91.9 & $\begin{array}{l}0.02 \text { to } \\
0.07 \\
(0.04)\end{array}$ & $\begin{array}{l}0.04 \text { to } \\
0.13 \\
(0.09)\end{array}$ \\
\hline & $\begin{array}{l}\text { OT } \\
\text { U } 3\end{array}$ & $\begin{array}{l}\text { Deferribacte } \\
\text { res }\end{array}$ & Deferribacteres & Deferribacterales & Deferribacteraceae & Deferribacter & 92.3 & $\begin{array}{l}0.29 \text { to } \\
1.27 \\
(0.84)\end{array}$ & $\begin{array}{l}1.01 \text { to } \\
2.41 \\
(1.75)\end{array}$ \\
\hline & $\begin{array}{l}\text { OT } \\
\text { U } 4\end{array}$ & $\begin{array}{l}\text { Deferribacte } \\
\text { res }\end{array}$ & Deferribacteres & Deferribacterales & Deferribacteraceae & Deferribacter & 92.1 & $\begin{array}{l}0.02 \text { to } \\
0.07 \\
(0.05)\end{array}$ & $\begin{array}{l}0.06 \text { to } \\
0.14 \\
(0.10)\end{array}$ \\
\hline & $\begin{array}{l}\text { OT } \\
\text { U } 5\end{array}$ & $\begin{array}{l}\text { Deferribacte } \\
\text { res }\end{array}$ & Deferribacteres & Deferribacterales & Deferribacteraceae & Deferribacter & 90.4 & $\begin{array}{l}0.12 \text { to } \\
0.49 \\
(0.33)\end{array}$ & $\begin{array}{l}0.39 \text { to } \\
0.96 \\
(0.69)\end{array}$ \\
\hline & $\begin{array}{l}\text { OT } \\
\text { U } 6\end{array}$ & $\begin{array}{l}\text { Deferribacte } \\
\text { res }\end{array}$ & Deferribacteres & Deferribacterales & Deferribacteraceae & Deferribacter & 92.4 & $\begin{array}{l}0.02 \text { to } \\
0.09 \\
(0.05)\end{array}$ & $\begin{array}{l}0.06 \text { to } \\
0.16 \\
(0.11)\end{array}$ \\
\hline & $\begin{array}{l}\text { OT } \\
\text { U } 7\end{array}$ & $\begin{array}{l}\text { Proteobacte } \\
\text { ria }\end{array}$ & $\begin{array}{l}\text { Deltaproteobacte } \\
\text { ria }\end{array}$ & $\begin{array}{l}\text { Desulfuromonadale } \\
\mathrm{s}\end{array}$ & Geobacteraceae & Geobacter $^{a}$ & 98.5 & $\begin{array}{l}0.01 \text { to } \\
0.04 \\
(0.02)\end{array}$ & $\begin{array}{l}0.03 \text { to } \\
0.12 \\
(0.07)\end{array}$ \\
\hline & $\begin{array}{l}\text { OT } \\
\cup 8\end{array}$ & Firmicutes & Clostridia & Clostridiales & Gracilibacteraceae & Gracilibacter & 92.2 & $\begin{array}{l}<0.01 \text { to } \\
0.0(0.0)\end{array}$ & $\begin{array}{l}<0.01 \text { to } \\
0.17 \\
(0.04)\end{array}$ \\
\hline
\end{tabular}




\begin{tabular}{|c|c|c|c|c|c|c|c|c|c|}
\hline & $\begin{array}{l}\text { OT } \\
\text { U } 9\end{array}$ & Firmicutes & Clostridia & Clostridiales & Gracilibacteraceae & Gracilibacter & 91.2 & $\begin{array}{l}0.03 \text { to } \\
0.07 \\
(0.04)\end{array}$ & $\begin{array}{l}0.06 \text { to } \\
1.69 \\
(0.28) \\
\end{array}$ \\
\hline & $\begin{array}{l}\text { OT } \\
U \\
10 \\
\end{array}$ & Firmicutes & Clostridia & Clostridiales & Gracilibacteraceae & Gracilibacter & 93.0 & $\begin{array}{l}<0.01 \text { to } \\
0.01 \\
(0.01)\end{array}$ & $\begin{array}{l}0.02 \text { to } \\
0.39 \\
(0.10) \\
\end{array}$ \\
\hline & $\begin{array}{l}\text { OT } \\
U \\
11 \\
\end{array}$ & $\begin{array}{l}\text { Thermotoga } \\
\text { e }\end{array}$ & Thermotogae & Thermotogales & Thermotogaceae & Kosmotoga $^{b}$ & 99.6 & $\begin{array}{l}0.49 \text { to } \\
2.28 \\
(1.23)\end{array}$ & $\begin{array}{l}2.16 \text { to } \\
5.06 \\
(3.26)\end{array}$ \\
\hline & $\begin{array}{l}\text { OT } \\
U \\
12 \\
\end{array}$ & Firmicutes & Negativicutes & Selenomonadales & Veillonellaceae & Pelosinus & 84.3 & $\begin{array}{l}<0.01 \text { to } \\
0.01 \\
(0.0)\end{array}$ & $\begin{array}{l}0.06 \text { to } \\
0.21 \\
(0.12)\end{array}$ \\
\hline & $\begin{array}{l}\text { OT } \\
U \\
13\end{array}$ & Firmicutes & Clostridia & Clostridiales & Clostridiales & $\begin{array}{l}\text { Pseudoflavonifra } \\
\text { ctor }\end{array}$ & 96.0 & $\begin{array}{l}<0.01 \text { to } \\
0.01 \\
(0.0)\end{array}$ & $\begin{array}{l}<0.01 \text { to } \\
0.16 \\
(0.04)\end{array}$ \\
\hline & $\begin{array}{l}\text { OT } \\
U \\
14 \\
\end{array}$ & Firmicutes & Clostridia & Clostridiales & Clostridiales & $\begin{array}{l}\text { Pseudoflavonifra } \\
\text { ctor }^{c}\end{array}$ & 97.1 & $\begin{array}{l}<0.01 \text { to } \\
0.0(0.0)\end{array}$ & $\begin{array}{l}<0.01 \text { to } \\
0.03 \\
(0.01)\end{array}$ \\
\hline & $\begin{array}{l}\text { OT } \\
U \\
15 \\
\end{array}$ & Firmicutes & Clostridia & Clostridiales & Ruminococcaceae & Ruminococcus & 93.4 & $\begin{array}{l}0.01 \text { to } \\
0.07 \\
(0.03)\end{array}$ & $\begin{array}{l}0.05 \text { to } \\
0.42 \\
(0.12)\end{array}$ \\
\hline & $\begin{array}{l}\text { OT } \\
U \\
16\end{array}$ & $\begin{array}{l}\text { Proteobacte } \\
\text { ria }\end{array}$ & $\begin{array}{l}\text { Deltaproteobacte } \\
\text { ria }\end{array}$ & $\begin{array}{l}\text { Syntrophobacterale } \\
\text { s }\end{array}$ & $\begin{array}{l}\text { Syntrophorhabdace } \\
\text { ae }\end{array}$ & $\begin{array}{l}\text { Syntrophorhabdu } \\
s\end{array}$ & 94.5 & $\begin{array}{l}0.04 \text { to } \\
0.08 \\
(0.06)\end{array}$ & $\begin{array}{l}0.05 \text { to } \\
0.2 \\
(0.11)\end{array}$ \\
\hline \multirow{4}{*}{$\begin{array}{l}\text { Negativ } \\
\text { ely } \\
\text { correlat } \\
\text { ed OTUs }\end{array}$} & $\begin{array}{l}\text { OT } \\
U \\
17\end{array}$ & $\begin{array}{l}\text { Bacteroidet } \\
\text { es }\end{array}$ & Bacteroidia & Bacteroidales & Bacteroidaceae & Bacteroides & 84.7 & $\begin{array}{l}0.02 \text { to } \\
1.35 \\
(0.55)\end{array}$ & $\begin{array}{l}<0.01 \text { to } \\
0.04 \\
(0.01)\end{array}$ \\
\hline & $\begin{array}{l}\text { OT } \\
U \\
18 \\
\end{array}$ & Chloroflexi & Anaerolineae & Anaerolineales & Anaerolineaceae & Bellilinea & 96.3 & $\begin{array}{l}0.21 \text { to } \\
1.75 \\
(0.78)\end{array}$ & $\begin{array}{l}0.03 \text { to } \\
0.27 \\
(0.13) \\
\end{array}$ \\
\hline & $\begin{array}{l}\text { OT } \\
U \\
19 \\
\end{array}$ & Chloroflexi & Anaerolineae & Anaerolineales & Anaerolineaceae & Bellilinea & 96.1 & $\begin{array}{l}0.01 \text { to } \\
0.11 \\
(0.04)\end{array}$ & $\begin{array}{l}<0.01 \text { to } \\
0.02 \\
(0.01) \\
\end{array}$ \\
\hline & $\begin{array}{l}\text { OT } \\
U \\
20\end{array}$ & Firmicutes & Clostridia & Clostridiales & Clostridiaceae & Clostridium & 93.0 & $\begin{array}{l}0.01 \text { to } \\
0.10 \\
(0.04)\end{array}$ & $\begin{array}{l}<0.01 \text { to } \\
0.02 \\
(0.01)\end{array}$ \\
\hline
\end{tabular}




\begin{tabular}{|c|c|c|c|c|c|c|c|c|}
\hline $\begin{array}{l}\text { OT } \\
U \\
21\end{array}$ & $\begin{array}{l}\text { Deferribacte } \\
\text { res }\end{array}$ & Deferribacteres & Deferribacterales & Deferribacteraceae & Deferribacter $^{d}$ & 99.6 & $\begin{array}{l}0.22 \text { to } \\
0.61 \\
(0.39)\end{array}$ & $\begin{array}{l}0.07 \text { to } \\
0.22 \\
(0.15) \\
\end{array}$ \\
\hline $\begin{array}{l}\text { OT } \\
U \\
22 \\
\end{array}$ & Firmicutes & Clostridia & Clostridiales & Eubacteriaceae & Eubacterium & 86.8 & $\begin{array}{l}0.11 \text { to } \\
2.23 \\
(0.68)\end{array}$ & $\begin{array}{l}0.03 \text { to } \\
0.25 \\
(0.11) \\
\end{array}$ \\
\hline $\begin{array}{l}\text { OT } \\
U \\
23\end{array}$ & $\begin{array}{l}\text { Proteobacte } \\
\text { ria }\end{array}$ & $\begin{array}{l}\text { Gammaproteobac } \\
\text { teria }\end{array}$ & Chromatiales & Halothiobacillaceae & Halothiobacillus & 73.6 & $\begin{array}{l}<0.01 \text { to } \\
0.16 \\
(0.04)\end{array}$ & $\begin{array}{l}<0.01 \text { to } \\
0.02 \\
(0.0)\end{array}$ \\
\hline $\begin{array}{l}\text { OT } \\
U \\
24\end{array}$ & $\begin{array}{l}\text { Planctomyc } \\
\text { etes }\end{array}$ & Planctomycetia & Planctomycetales & Planctomycetaceae & Planctomyces & 87.5 & $\begin{array}{l}0.02 \text { to } \\
0.53 \\
(0.17)\end{array}$ & $\begin{array}{l}<0.01 \text { to } \\
0.08 \\
(0.03) \\
\end{array}$ \\
\hline $\begin{array}{l}\text { OT } \\
U \\
25\end{array}$ & $\begin{array}{l}\text { Bacteroidet } \\
\text { es }\end{array}$ & Bacteroidia & Bacteroidales & $\begin{array}{l}\text { Porphyromonadacea } \\
\text { e }\end{array}$ & Proteiniphilum $^{e}$ & 98.5 & $\begin{array}{l}0.02 \text { to } \\
0.10 \\
(0.05)\end{array}$ & $\begin{array}{l}<0.01 \text { to } \\
0.03 \\
(0.02)\end{array}$ \\
\hline $\begin{array}{l}\text { OT } \\
U \\
26\end{array}$ & $\begin{array}{l}\text { Proteobacte } \\
\text { ria }\end{array}$ & $\begin{array}{l}\text { Gammaproteobac } \\
\text { teria }\end{array}$ & Alteromonadales & $\begin{array}{l}\text { Pseudoalteromonad } \\
\text { aceae }\end{array}$ & $\begin{array}{l}\text { Pseudoalteromon } \\
\text { as }\end{array}$ & 89.1 & $\begin{array}{l}0.24 \text { to } \\
6.97 \\
(3.05)\end{array}$ & $\begin{array}{l}0.07 \text { to } \\
1.23 \\
(0.24) \\
\end{array}$ \\
\hline $\begin{array}{l}\text { OT } \\
U \\
27\end{array}$ & $\begin{array}{l}\text { Proteobacte } \\
\text { ria }\end{array}$ & $\begin{array}{l}\text { Gammaproteobac } \\
\text { teria }\end{array}$ & Alteromonadales & $\begin{array}{l}\text { Pseudoalteromonad } \\
\text { aceae }\end{array}$ & $\begin{array}{l}\text { Pseudoalteromon } \\
\text { as }\end{array}$ & 85.7 & $\begin{array}{l}<0.01 \text { to } \\
0.16 \\
(0.06)\end{array}$ & $\begin{array}{l}<0.01 \text { to } \\
0.02 \\
(0.0)\end{array}$ \\
\hline $\begin{array}{l}\text { OT } \\
U \\
28\end{array}$ & $\begin{array}{l}\text { Bacteroidet } \\
\text { es }\end{array}$ & Sphingobacteriia & Sphingobacteriales & Sphingobacteriaceae & $\begin{array}{l}\text { Sphingobacteriu } \\
\mathrm{m}\end{array}$ & 84.2 & $\begin{array}{l}0.04 \text { to } \\
1.63 \\
(0.69)\end{array}$ & $\begin{array}{l}<0.01 \text { to } \\
0.05 \\
(0.02)\end{array}$ \\
\hline $\begin{array}{l}\text { OT } \\
U \\
29\end{array}$ & Firmicutes & Clostridia & Clostridiales & Symbiobacteriaceae & $\begin{array}{l}\text { Symbiobacteriu } \\
\text { m }\end{array}$ & 95.6 & $\begin{array}{l}0.03 \text { to } \\
0.20 \\
(0.06)\end{array}$ & $\begin{array}{l}<0.01 \text { to } \\
0.06 \\
(0.02)\end{array}$ \\
\hline $\begin{array}{l}\text { otu } \\
30\end{array}$ & firmicutes & clostridia & $\begin{array}{l}\text { thermoanaerobact } \\
\text { erales }\end{array}$ & $\begin{array}{l}\text { thermoanaerobacter } \\
\text { ales family iii. } \\
\text { incertae sedis }\end{array}$ & $\begin{array}{l}\text { thermovenabulu } \\
m\end{array}$ & 83.5 & $\begin{array}{l}0.15 \text { to } \\
0.99 \\
(0.44)\end{array}$ & $\begin{array}{l}0.01 \text { to } \\
0.41 \\
(0.08)\end{array}$ \\
\hline
\end{tabular}

a >97\% homology; uncultured Geobacter sp.

b >97\% homology; ay692052.1 UASB reactor clone $\mathrm{m} 79$.

c >97\% homology; uncultured Pseudoflavonifractor sp.

d $>97 \%$ homology; uncultured Deferribacter sp.

e $>97 \%$ homology; uncultured Proteiniphilum sp. 
Previous studies on anaerobic digestion of complex carbon substrates have also resulted in similar findings. Yue et al. (2013) reported a significant shift in digester bacterial community, compared to the archaeal community, when the substrate composition changed after co-digestion of cattle manure with corn stover was initiated. Conversely, both bacterial and archaeal communities changed significantly when only the SRT value of the co-digesters was varied (Yue et al., 2013).

Similarly, Ziganshin et al. (2013) reported that bacterial communities were influenced significantly by varying substrate composition during anaerobic co-digestion of cattle manure with various agricultural residues (chicken manure, distillers grain, maize silage, maize straw and jatropha cake), and both bacterial and archaeal communities were influenced by other factors, such as digester operating temperature, SRT and organic loading rate.

OTUs most similar to Kosmotoga and Deferribacter became more dominant after PHB co-digestion as indicated by relative abundance values (Table 1). The taxonomic identification of the positively correlated bacterial OTUs were distinct from the negatively correlated OTUs. Except for one negatively correlated OTU of genus Deferribacter (OTU 21), the genera of the 13 remaining negatively correlated OTUs were not represented among the 16 positively correlated OTUs (Table 1).

The significant OTU relative abundance values were less similar (ANOSIM R $=0.91, p=0.001$ ) than those of the major bacterial OTUs when comparing pre- and post-co-digestion quasi steady state periods (Fig. $2 \mathrm{~B}$ and D). Relative abundance heatmap with dual hierarchical clustering of the 30 significant OTUs illustrates a major shift from pre to post-co-digestion. Taxa with relative abundance values that positively (OTUs 1-16) and negatively (OTUs 17-30) correlated with methane production clustered into two branches. Likewise, pre and post-co-digestion samples clustered into two distinct branches with post-co-digestion samples primarily clustered by presence or absence of pretreatment, but not by PHB type. Pre-co-digestion samples showed no clustering pattern. Sample clustering depicted a clear differentiation between pre and post-co-digestion communities and the influence of PHB treatment on microbial community composition. The combined relative abundance of the 16 positively correlated OTUs increased from $2.8 \pm 0.6 \%$ during pre-co-digestion to $7.1 \pm 1.2 \%$ during postco-digestion. Conversely, the combined relative abundance of the 14 negatively correlated OTUs decreased from $7.2 \pm 3.0 \%$ during pre-co-digestion to $0.8 \pm 0.3 \%$ during the co-digestion period.

Relative abundance values of significant OTUs changed and converged for all digesters after each bioplastic was co-digested (Fig. $3 \mathrm{~A}$ and $\mathrm{B}$ ). Pre- and post-co-digestion quasi steady state and transition period relative abundance value similarity was quantified using the ANOSIM statistic value (R) and employed the significant OTU data (ANOSIM data values). Co-digesters were able to more quickly adapt and exhibited shorter lag times when pre-co-digestion communities were less similar to transition period communities (Fig. 4A) and when transition communities were more similar to postco-digestion communities (Fig. 4C). In addition, cumulative transition period methane production was higher when pre-co-digestion and transition period communities were less similar (Fig. 4B), or when transition versus post-co-digestion communities were more similar (Fig. 4D). Conversely, co-digesters with shorter lag times and higher cumulative transition period methane production showed more similarity between post-co-digestion and transition period communities. The community shift in the 342 major bacterial OTUs during pre-, transition- and post-co-digestion periods were also compared with the observed difference in lag time and cumulative transition period methane production. 
However, the shift in the major bacterial OTUs did not show a strong correlation like that observed using the 30 significant OTUs (ANOSIM data values).
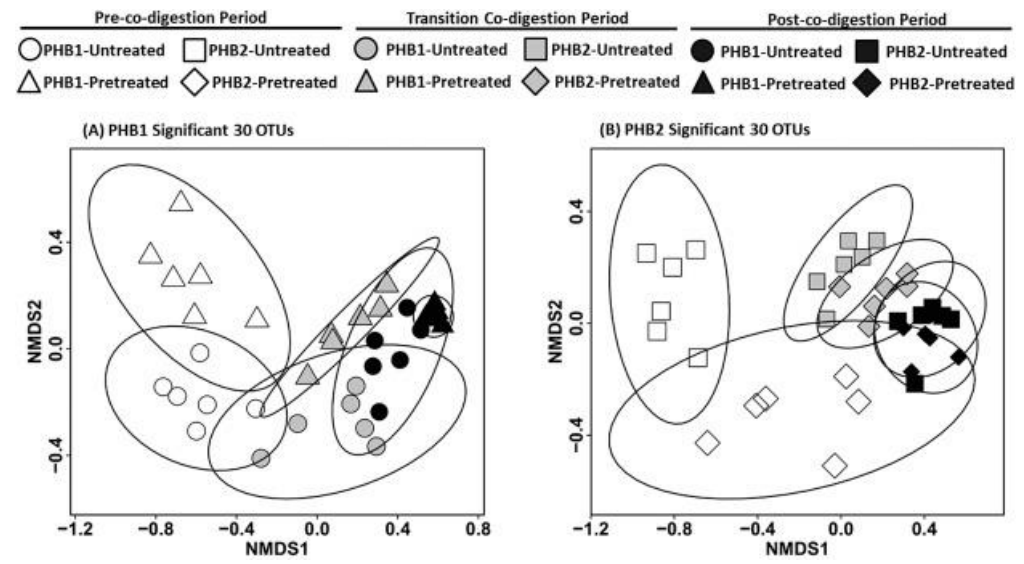

Fig. 3. Communities comparison NMDS plots during pre-, transition- and post-co-digestion periods for digesters receiving (A) PHB1 and (B) PHB2 based on the 30 significant OTUs having relative abundance values related to methane production rate using Spearman's rank correlation.

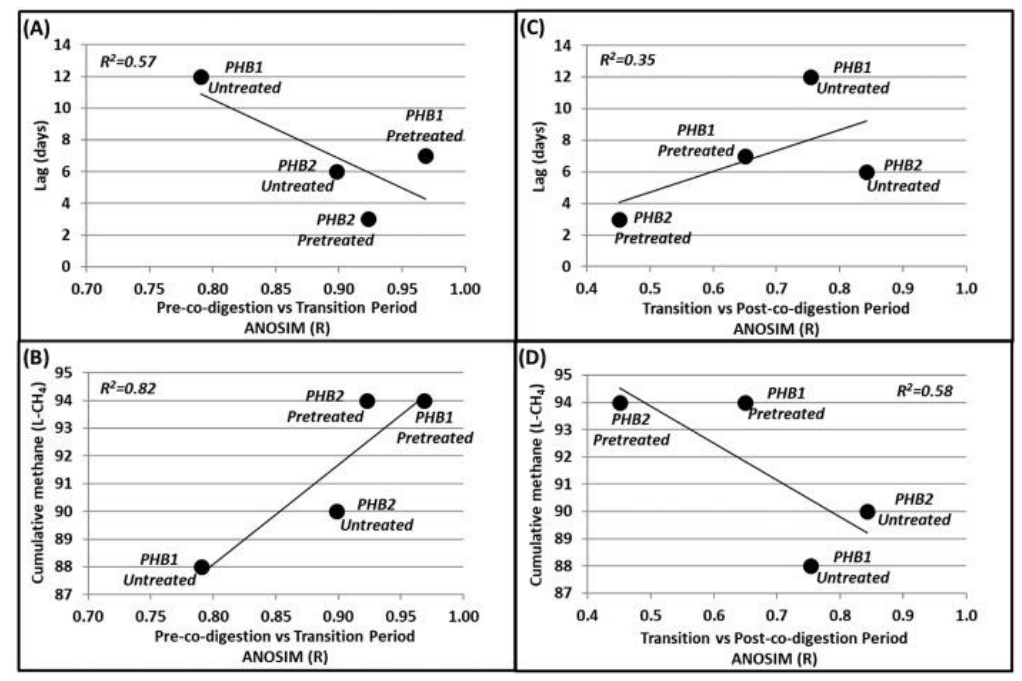

Fig. 4. Similarity of pre-co-digestion and transition period microbial communities versus (A) lag time before post-co-digestion PHB methane production commenced and (B) cumulative methane produced during the transition period. Similarity between transition and post-co-digestion period microbial communities versus (C) lag time before post-co-digestion PHB methane production commenced and (D) cumulative transition period methane produced. Community similarity was quantified by the ANOSIM statistic value (R). ANOSIM was performed using the 30 significant OTUS having relative abundance values that related to methane production rate using Spearman's rank correlation.

Factors such as the change in OLR brought about by PHB co-digestion could influence the microbial community due to potential changes in the digester $\mathrm{pH}$, VFA concentration or other parameters. However, the OLR increased only $20 \%$ during PHB co-digestion, and no drop in pH or high VFA production ( $<50 \mathrm{mg} / \mathrm{L}$ ) was observed after bioplastic co-digestion. On the other hand, substrate composition is also known to influence microbial community composition in anaerobic digesters (Noike et al., 1985; Álvarez et al., 2010; Cesaro and Belgiorno, 2014). Therefore, it is more likely that change in 
significant OTU relative abundance was due to the change in substrate composition after co-digestion started rather than due to OLR increase.

\subsection{The role of positively correlated OTUs in anaerobic PHB degradation}

Of the known PHA or PHB degrading bacteria, only the genera Streptomyces and Bacillus were most similar to OTUs identified in this study (Janssen and Harfoot, 1990; Budwill et al., 1996; Mergaert et al., 1996; Abou-Zeid et al., 2001; Emadian et al., 2017). However, the relative abundance values of Streptomyces and Bacillus OTUs were relatively low (<0.001\%) and did not significantly increase after PHB addition. In addition, none of the 16 positively correlated OTUs were previously reported to have a role in PHB degradation. Microbial degradation of bio-polymers such as PHB or PHA requires extracellular enzymes such PHA depolymerase and lipase (Rodríguez-Contreras et al., 2012; Banerjee et al., 2014). Taxa to which the 30 significant OTUs were most similar were compared to a current list of microorganisms that possess PHA depolymerase or lipase enzymes (Pleiss et al., 2000; Knoll et al., 2009). None of the 30 significant OTUs were found in the PHA depolymerase database. Two positively

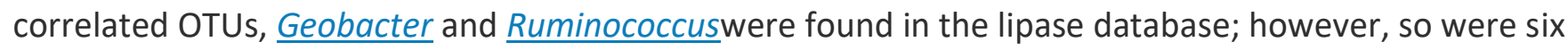
of the negatively correlated

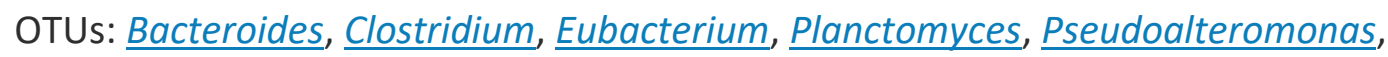
and Symbiobacterium.

Several of the positively correlated significant OTUs have been previously identified for their fermentative and acetogenic function during anaerobic digestion. Deferribacter and Pseudoflavonifractor are known acidogenic amino acid degraders (Talbot et al., 2008; Jumas-Bilak et al., 2009; Cardinali-Rezende et al.,

2016). Geobacter and Syntrophorhabdus are known for direct interspecies electron transfer (DIET) in anaerobic digestion and generally are important syntrophic bacteria co-occurring symbiotically with hydrogenotrophic methanogens (Mclnerney et al., 2007; Shen et al., 2016). Gracilibacter thermotolerans, the only Gracilibacter taxa characterized, is defined as acidogenic, obligate anaerobe and ferments a number of carbohydrates yielding acetate, lactate and ethanol (Lee et al., 2006). Members of the order Thermotogales,

including Kosmotoga, Fervidobacterium and Geotoga, are well characterized carbohydrate hydrolyzers and fermenters, and proliferate in anaerobic digesters (Ju et al., 2017; Peces et al., 2018; Wang et al., 2018). Pelosinus is a strict anaerobe and has been associated with acetogenic fermentation of lactate through the expression of hydrolyzing lipase enzymes (Jaeger et al., 1995; Roohi et al., 2018). Members of the genera Ruminococcus are anaerobic and cellulolytic bacteria which play an important role in the hydrolysis and fermentation of hemicellulosic and cellulosic materials during anaerobic digestion (Yi et al., 2014).

Most current knowledge regarding PHB-degrading microorganisms is based on isolates from natural environments such as soil or river sediments contaminated by PHB. In contrast, reports regarding microbial communities during anaerobic co-digestion of PHB are lacking. The results of this study show that anaerobic co-digestion of PHB and SMPS significantly impacts the relative abundance of specific bacteria that are have not been previously identified to be involved in PHB degradation. In addition, none of the currently known PHA degrading microorganisms were observed to play a significant role in anaerobic PHB co-digestion. Therefore, there may be as-yet-unknown PHB degrading bacteria. The 
hydrolytic and lipolytic activities of the diverse bacterial community in an anaerobic digester treating primary sludge are sufficient to co-digest PHB polymers. The results of this study confirm that municipal water reclamation facilities with excess capacity could co-digest PHB bioplastic in addition to municipal wastewater sludge to generate more methane and renewable energy. Furthermore, pretreatment of bioplastics at high temperature and $\mathrm{pH}$ can further help by decreasing lag time and increasing methane production immediately after PHB bioplastic co-digestion is initiated.

New insights into the microbial community of PHB co-digesters can further the advancement of sustainable bioplastic waste management strategies. Fundamental knowledge of the complex microbial consortia needed for successful PHB co-digestion is useful for monitoring startup operations when full-scale bioplastic co-digestion is initiated. Troubleshooting full-scale bioplastic co-digestion can also be accomplished through observation of the microbial community and may help to predict lag time associated with community acclimation. Predicting methane production rate from relative abundance data of the significant OTUs identified herein may further improve co-digester design and in the selection of co-digester inoculum in the future (Venkiteshwaran et al., 2017).

\section{Conclusion}

Methane production increased as a result of PHB co-digestion with no change in digester performance. Pretreatment of PHB bioplastic at high pH and temperature initially reduced the lag time before methane production increased when PHB co-digestion began. PHB co-digester bacterial communities changed, whereas no archaeal community change was observed.

No previously known PHB degraders were observed in the co-digesters. OTUs most similar to Deferribacter, Geobacter, Kosmotoga, and Ruminococcus were found to correlate positively with increased methane production resulting from PHB co-digestion. These OTUs may play an important role in PHB bioplastic conversion to methane in anaerobic digestion.

\section{Conflict of interest}

The authors declare that they have no known competing financial interests or personal relationships that could have appeared to influence the work reported in this paper.

\section{Acknowledgements}

This work was supported by the National Science Foundation under Award No. 1540010 to Marquette University for the Water Equipment and Policy Industry/University Cooperative Research Center. The authors thank Mango Materials for providing PHB1 and PHB2 test materials.

\section{References}

\section{Abou-Zeid et al., 2001}

D.-M. Abou-Zeid, R.-J. Mü, W.-D. Deckwer, Degradation of natural and synthetic polyesters under anaerobic conditions. J. Biotechnol., 86 (2001), pp. 113-126

Ali Shah et al., 2008

\section{A. Ali Shah, F. Hasan, A. Hameed, S. Ahmed, Biological degradation of plastics: a comprehensive} review. Biotechnol. Adv., 26 (2008), pp. 246-265, 10.1016/j.biotechadv.2007.12.005 
S.F. Altschul, W. Gish, W. Miller, E.W. Myers, D.J. Lipman, Basic local alignment search tool. J. Mol. Biol., 215 (1990), pp. 403-410, 10.1016/S0022-2836(05)80360-2

Álvarez et al., 2010

J.A. Álvarez, L. Otero, J.M. Lema, A methodology for optimising feed composition for anaerobic codigestion of agro-industrial wastes. Bioresour. Technol., 101 (2010), pp. 1153-

1158, 10.1016/j.biortech.2009.09.061

APHA et al., 1999

APHA, AWWA, WEF, Standard Methods for the Examination of Water and Wastewater. (20th ed.), American Public Health Association Publications, Washington, DC (1999), p. 20460 Banerjee et al., 2014

A. Banerjee, K. Chatterjee, G. Madras, Enzymatic degradation of polymers: a brief review. Mater. Sci. Technol., 30 (2014), pp. 567-573, 10.1179/1743284713Y.0000000503

Benn and Zitomer, 2018

N. Benn, D. Zitomer, Pretreatment and anaerobic co-digestion of selected PHB and PLA bioplastics. Front. Environ. Sci., 5 (2018), 10.3389/fenvs.2017.00093

Briones et al., 2007

A.M. Briones, B.J. Daugherty, L.T. Angenent, K.D. Rausch, M.E. Tumbleson, L. Raskin, Microbial diversity and dynamics in multi- and single-compartment anaerobic bioreactors processing sulfate-rich waste streams. Environ. Microbiol., 9 (2007), pp. 93-106, 10.1111/j.14622920.2006.01119.x

Budwill, 1996

K. Budwill, Anaerobic microbial degradation of poly(3-hydroxyalkanoates) with various terminal electron acceptors. J. Environ. Polym. Degrad., 4 (1996), pp. 91-102, 10.1007/BF02074870

Budwill et al., 1992

K. Budwill, P.M. Fedorak, W.J. Page, Methanogenic degradation of poly(3-hydroxyalkanoates). Appl. Environ. Microbiol., 58 (1992), pp. 1398-1401

Budwill et al., 1996

K. Budwill, P.M. Fedorak, W.J. Page, Anaerobic microbial degradation of poly (3-hydroxyalkanoates) with various terminal electron acceptors. J. Environ. Polym. Degrad., 4 (1996), pp. 91$102,10.1007 / B F 02074870$

Buswell and Mueller, 1952

A.M. Buswell, H.F. Mueller, Mechanism of methane fermentation. Ind. Eng. Chem., 44 (1952), pp. 550552

Cardinali-Rezende et al., 2016

J. Cardinali-Rezende, P. Rojas-Ojeda, A.M.Nascimento, J.L. Sanz, Proteolytic bacterial dominance in a full-scale municipal solid waste anaerobic reactor assessed by $\mathbf{4 5 4}$ pyrosequencing technology. Chemosphere, 146 (2016), pp. 519-525, 10.1016/i.chemosphere.2015.12.003

Carey et al., 2016

D.E. Carey, D.H. Zitomer, K.R. Hristova, A.D. Kappell, P.J.McNamara, Triclocarban influences antibiotic resistance and alters anaerobic digester microbial community structure. Environ. Sci.

Technol., 50 (2016), pp. 126-134, 10.1021/acs.est.5b03080

Cesaro and Belgiorno, 2014

A. Cesaro, V. Belgiorno, Pretreatment methods to improve anaerobic biodegradability of organic municipal solid waste fractions. Chem. Eng. J. (2014), 10.1016/j.cej.2013.11.055

Conklin et al., 2006 
A. Conklin, H.D. Stensel, J. Ferguson, Growth kinetics and competition between Methanosarcina and Methanosaeta in mesophilic anaerobic digestion. Water Environ. Res., 78 (2006), pp. 486-496

Criddle et al., 2014

C.S. Criddle, S.L. Billington, C.W Frank, Renewable Bioplastics and Biocomposites From Biogas Methane and Waste-Derived Feedstock: Development of Enabling Technology, Life Cycle Assessment, and Analysis of Costs. California Department of Resources Recycle and Recovery (2014) Publication number: DRRR-2014-1502

https://www2.calrecycle.ca.gov/Publications/Details/1502

Dörner and Schink, 1990

C. Dörner, B. Schink, Clostridium homopropionicum sp. nov., a new strict anaerobe growing with 2-, 3-, or 4-hydroxybutyrate. Arch. Microbiol., 154 (1990), pp. 342-348, 10.1007/BF00276529

Emadian et al., 2017

S.M. Emadian, T.T. Onay, B. Demirel, Biodegradation of bioplastics in natural environments. Waste Manag., 59 (2017), pp. 526-536, 10.1016/j.wasman.2016.10.006

\section{Falk et al., 2009}

M.W. Falk, K.G. Song, M.G. Matiasek, S. Wuertz, Microbial community dynamics in replicate membrane bioreactors - natural reproducible fluctuations. Water Res., 43 (2009), pp. 842852, 10.1016/j.watres.2008.11.021

Fox and Weisberg, 2011

J. Fox, S. Weisberg, An R Companion to Applied Regression. SAGE (2011), 10.1177/0049124105277200 Getachew and Woldesenbet, 2016

A. Getachew, F. Woldesenbet, Production of biodegradable plastic by polyhydroxybutyrate (PHB) accumulating bacteria using low cost agricultural waste material. BMC Res. Notes, 9 (2016), Article 509, 10.1186/s13104-016-2321-y

Geyer et al., 2017

R. Geyer, J.R. Jambeck, K.L. Law, Production, use, and fate of all plastics ever made. Sci. Adv., 3 (2017) Hori et al., 2006

T. Hori, S. Haruta, Y. Ueno, M. Ishii, Y. Igarashi, Dynamic transition of a methanogenic population in response to the concentration of volatile fatty acids in a thermophilic anaerobic digester. Appl. Environ. Microbiol., 72 (2006), pp. 1623-1630, 10.1128/AEM.72.2.1623-1630.2006 Jaeger et al., 1995

K.E. Jaeger, A. Steinbüchel, D. Jendrossek, Substrate specificities of bacterial polyhydroxyalkanoate depolymerases and lipases: bacterial lipases hydrolyze poly(omega-hydroxyalkanoates). Appl. Environ. Microbiol., 61 (1995), pp. 3113-3118

Janssen and Harfoot, 1990

P.H. Janssen, C.G. Harfoot, Ilyobacter delafieldii sp. nov., a metabolically restricted anaerobic bacterium fermenting PHB. Arch. Microbiol., 154 (1990), pp. 253-259, 10.1007/BF00248964

Janssen and Schink, 1993

P.H. Janssen, B. Schink, Pathway of anaerobic poly- $\beta$-hydroxybutyrate degradation by Ilyobacter delafieldii. Biodegradation, 4 (1993), pp. 179-185, 10.1007/BF00695120

Ju et al., 2017

F. Ju, F. Lau, T. Zhang, Linking microbial community, environmental variables, and methanogenesis in anaerobic biogas digesters of chemically enhanced primary treatment sludge. Environ. Sci. Technol., 51 (2017), pp. 3982-3992, 10.1021/acs.est.6b06344

Jumas-Bilak et al., 2009 
E. Jumas-Bilak, L. Roudière, H. Marchandin, Description of 'Synergistetes' phyl. nov. and emended description of the phylum 'Deferribacteres' and of the family Syntrophomonadaceae, phylum 'Firmicutes. Int. J. Syst. Evol. Microbiol., 59 (2009), pp. 1028-1035, 10.1099/ijs.0.006718-0

$\underline{\text { Kalia et al., } 2000}$

V.C. Kalia, N. Raizada, V. Sonakya, Bioplastics. J. Sci. Ind. Res., 59 (2000), pp. 433-445

Knoll et al., 2009

M. Knoll, T.M. Hamm, F. Wagner, V. Martinez, J. Pleiss, The PHA Depolymerase Engineering Database: a systematic analysis tool for the diverse family of polyhydroxyalkanoate (PHA) depolymerases. BMC Bioinformatics, 10 (2009), p. 89, 10.1186/1471-2105-10-89

Kourmentza et al., 2017

C. Kourmentza, J. Plácido, N. Venetsaneas, A. Burniol-

Figols, C. Varrone, H.N. Gavala, M.A.M. Reis, C. Kourmentza, J. Plácido, N.Venetsaneas, A. Burni ol-Figols, C. Varrone, H.N. Gavala, M.A.M. Reis, Recent advances and challenges towards sustainable polyhydroxyalkanoate (PHA) production. Bioengineering, 4 (2017), p. 55, 10.3390/bioengineering4020055

Kurade et al., 2019

M.B. Kurade, S. Saha, E.-S. Salama, S.M. Patil, S.P. Govindwar, B.-H. Jeon, Acetoclastic methanogenesis led by Methanosarcina in anaerobic co-digestion of fats, oil and grease for enhanced production of methane. Bioresour. Technol., 272 (2019), pp. 351-

359, 10.1016/j.biortech.2018.10.047

Lee et al., 2006

Y.-J. Lee, C.S. Romaneck, G.L. Mills, R.C. Davis, W.B. Whitman, J.Wiegel, Gracilibacter thermotolerans gen. nov., sp. nov., an anaerobic, thermotolerant bacterium from a constructed wetland receiving acid sulfate water. Int. J. Syst. Evol. Microbiol., 56 (2006), pp. 2089-

2093, 10.1099/ijs.0.64040-0

Mato et al., 2001

Y. Mato, T. Isobe, H. Takada, H. Kanehiro, C. Ohtake, T.Kaminuma, Plastic resin pellets as a transport medium for toxic chemicals in the marine environment. Environ. Sci. Technol., 35 (2001), pp. 318-324, 10.1021/es0010498

Mclnerney et al., 2007

M.J. McInerney, L. Rohlin, H. Mouttaki, U. Kim, R.S.Krupp, L. RiosHernandez, J. Sieber, C.G. Struchtemeyer, A. Bhattacharyya, J.W. Campbell, R.P. Gunsalus, The genome of Syntrophus aciditrophicus: life at the thermodynamic limit of microbial growth.

Proc. Natl. Acad. Sci. U. S. A., 104 (2007), pp. 7600-7605, 10.1073/pnas.0610456104

Mcmurdie and Holmes, 2013

P.J. Mcmurdie, S. Holmes, phyloseq: an R package for reproducible interactive analysis and graphics of microbiome census data. PLoS One, 8 (2013), 10.1371/journal.pone.0061217

Mergaert et al., 1996

J. Mergaert, G. Glorieux, L. Hauben, V. Storms, M. Mau, J.Swings, Biodegradation of Poly (3 hydroxyalkanoates) in anaerobic sludge and characterization of a poly (3 -hydroxyalkanoates) degrading anaerobic bacterium. Syst. Appl. Microbiol., 19 (1996), pp. 407-413, 10.1016/S07232020(96)80070-1

Narodoslawsky et al., 2015

M. Narodoslawsky, K. Shazad, R. Kollmann, H.Schnitzer, LCA of PHA production - identifying the ecological potential of bio-plastic. Chem. Biochem. Eng. Q., 29 (2015), pp. 299-

305, 10.15255/CABEQ.2014.2262 


\section{Noike et al., 1985}

T. Noike, G. Endo, J.E. Chang, J. Yaguchi, J. Matsumoto, Characteristics of carbohydrate degradation and the rate-limiting step in anaerobic digestion. Biotechnol. Bioeng., 27 (1985), pp. 14821489, 10.1002/bit.260271013

Oksanen et al., 2016

J. Oksanen, F.G. Blanchet, R. Kindt, P. Legendre, P.R.Minchin, R.B. O'Hara, G.L. Simpson, P. Solymos, M. Henry, H. Stevens, H.Wagner, Vegan: Community Ecology Package. R Package Version 2.3-4. (2016) https://cran.r-project.org/

Peces et al., 2018

M. Peces, S. Astals, P.D. Jensen, W.P. Clarke, Deterministic mechanisms define the long-term anaerobic digestion microbiome and its functionality regardless of the initial microbial community. Water Res., 141 (2018), pp. 366-376, 10.1016/j.watres.2018.05.028

Pieja et al., 2011a

A.J. Pieja, K.H. Rostkowski, C.S. Criddle, Distribution and selection of poly-3-hydroxybutyrate production capacity in methanotrophic proteobacteria. Microb. Ecol., 62 (2011), pp. 564$573,10.1007 / \mathrm{s} 00248-011-9873-0$

Pieja et al., 2011b

A.J. Pieja, E.R. Sundstrom, C.S. Criddle, Poly-3-hydroxybutyrate metabolism in the type II Methanotroph Methylocystis parvus OBBP. Appl. Environ. Microbiol., 77 (2011), pp. 60126019, 10.1128/AEM.00509-11

Pleiss et al., 2000

J. Pleiss, M. Fischer, M. Peiker, C. Thiele, R.D. Schmid, Lipase engineering database: understanding and exploiting sequence-structure-function relationships. J. Mol. Catal. - B Enzym., 10 (2000), pp. 491-508, 10.1016/S1381-1177(00)00092-8

Rochman et al., 2016

C.M. Rochman, M.A. Browne, A.J. Underwood, J.A. van Franeker, R.C. Thompson, L.A. Amaral-Zettler, The ecological impacts of marine debris: unraveling the demonstrated evidence from what is perceived. Ecology, 97 (2016), pp. 302-312, 10.1890/14-2070.1

Rodríguez-Contreras et al., 2012

A. Rodríguez-Contreras, C.-M. Margarita, M.-C.María Soledad, Enzymatic degradation of poly(3hydroxybutyrate) by a commercial lipase. Polym. Degrad. Stab., 97 (2012), pp. 2473-

2476, 10.1016/j.polymdegradstab. 2012.07.042

Roohi et al., 2018

Roohi, M.R. Zaheer, M. Kuddus, PHB (poly- $\beta$-hydroxybutyrate) and its enzymatic degradation. Polym. Adv. Technol. (2018), 10.1002/pat.4126

Shen et al., 2016

L. Shen, Q. Zhao, X. Wu, X. Li, Q. Li, Y. Wang, Interspecies electron transfer in syntrophic methanogenic consortia: from cultures to bioreactors. Renew. Sust. Energ. Rev., 54 (2016), pp. 1358-1367, 10.1016/j.rser.2015.10.102

Talbot et al., 2008

G. Talbot, E. Topp, M.F. Palin, D.I. Massé, Review evaluation of molecular methods used for establishing the interactions and functions of microorganisms in anaerobic bioreactors. Water Res., 42 (2008), pp. 513-537, 10.1016/j.watres.2007.08.003

Tokiwa and Calabia, 2004

Y. Tokiwa, B.P. Calabia, Degradation of microbial polyesters. Biotechnol. Lett., 26 (2004), pp. 11811189, 10.1023/B:BILE.0000036599.15302.e5 
Tokiwa et al., 2009

Y. Tokiwa, B.P. Calabia, C.U. Ugwu, S. Aiba, Biodegradability of plastics. Int. J. Mol.

Sci. (2009), 10.3390/ijms10093722

Venkiteshwaran et al., 2017

K. Venkiteshwaran, K. Milferstedt, J. Hamelin, M.Fujimoto, M. Johnson, D.H. Zitomer, Correlating methane production to microbiota in anaerobic digesters fed synthetic wastewater. Water Res., 110 (2017), 10.1016/j.watres.2016.12.010

Verlinden et al., 2007

R.A.J. Verlinden, D.J. Hill, M.A. Kenward, C.D. Williams, I.Radecka, Bacterial synthesis of biodegradable polyhydroxyalkanoates. J. Appl. Microbiol. (2007), 10.1111/j.1365-2672.2007.03335.x

Wang et al., 2015

D. Wang, J. Zhao, G. Zeng, Y. Chen, P.L. Bond, X. Li, How does poly(hydroxyalkanoate) affect methane production from the anaerobic digestion of waste-activated sludge? Environ. Sci.

Technol., 49 (2015), pp. 12253-12262, 10.1021/acs.est.5b03112

Wang et al., 2018

P. Wang, H. Wang, Y. Qiu, L. Ren, B. Jiang, Microbial characteristics in anaerobic digestion process of food waste for methane production-a review. Bioresour. Technol., 248 (2018), pp. 29-

$36,10.1016 /$ j.biortech.2017.06.152

Witt et al., 2001

U. Witt, T. Einig, M. Yamamoto, I. Kleeberg, W.-D. Deckwer, R.-J.Müller, Biodegradation of aliphaticaromatic copolyesters: evaluation of the final biodegradability and ecotoxicological impact of degradation intermediates. Chemosphere, 44 (2001), pp. 289-299, 10.1016/S0045$\underline{6535(00) 00162-4}$

Yagi et al., 2013

H. Yagi, F. Ninomiya, M. Funabashi, M. Kunioka, Thermophilic anaerobic biodegradation test and analysis of eubacteria involved in anaerobic biodegradation of four specified biodegradable polyesters. Polym. Degrad. Stab., 98 (2013), pp. 1182-1187, 10.1016/i.polymdegradstab. $\underline{2013.03 .010}$

Yagi et al., 2014

H. Yagi, F. Ninomiya, M. Funabashi, M. Kunioka, Mesophilic anaerobic biodegradation test and analysis of eubacteria and archaea involved in anaerobic biodegradation of four specified biodegradable polyesters. Polym. Degrad. Stab., 110 (2014), pp. 278-

283, 10.1016/i.polymdegradstab. 2014.08.031

Yi et al., 2014

J. Yi, B. Dong, J. Jin, X. Dai, Effect of increasing total solids contents on anaerobic digestion of food waste under mesophilic conditions: performance and microbial characteristics analysis. PLOS One, 9 (2014), Article e102548, 10.1371/journal.pone.0102548

Yoshie et al., 2002

N. Yoshie, Y. Oike, K.I. Kasuya, Y. Doi, Y. Inoue, Change of surface structure of poly(3-hydroxybutyrate) film upon enzymatic hydrolysis by PHB depolymerase. Biomacromolecules, 3 (2002), pp. 13201326, 10.1021/bm020077a

$\underline{\text { Yu et al., } 2005}$

J. Yu, D. Plackett, L.X.L. Chen, Kinetics and mechanism of the monomeric products from abiotic hydrolysis of poly[(R)-3-hydroxybutyrate] under acidic and alkaline conditions. Polym. Degrad. Stab., 89 (2005), pp. 289-299, 10.1016/j.polymdegradstab. 2004.12.026

Yue et al., 2013 
Z.-B. Yue, T.L. Marsh, Y. Liu, Z. Yue, R. Chen, F. Yang, J. Maclellan, T. Marsh, W. Liao, Effects of dairy manure and corn stover co-digestion on anaerobic microbes and corresponding digestion performance. Bioresour. Technol., 128 (2013), pp. 65-71, 10.1016/j.biortech.2012.10.115

Ziganshin et al., 2013

A.M. Ziganshin, J. Liebetrau, J. Pröter, S. Kleinsteuber, Microbial community structure and dynamics during anaerobic digestion of various agricultural waste materials. Appl. Microbiol.

Biotechnol., 97 (2013), pp. 5161-5174, 10.1007/s00253-013-4867-0

Zuur et al., 2007

A. Zuur, E.N. Ieno, G.M. Smith, Analysing Ecological Data. Springer Science \& Business Media (2007) 